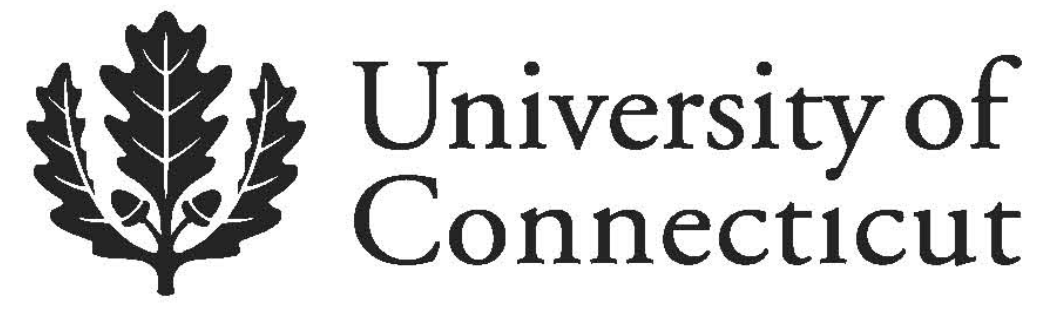

Department of Economics Working Paper Series

\title{
A temporal analysis of wealth in eighteenth-century Ottoman Kastamonu
}

Metin M. Coşgel

University of Connecticut

Boğaç A. Ergene

University of Vermont

Atabey Kaygun

Bahçeşehir University

Working Paper 2013-03

February 2013

365 Fairfield Way, Unit 1063

Storrs, CT 06269-1063

Phone: (860) 486-3022

Fax: (860) 486-4463

http://www.econ.uconn.edu/

This working paper is indexed on RePEc, http://repec.org 


\title{
A temporal analysis of wealth in eighteenth-century Ottoman Kastamonu
}

\author{
METIN COŞGEL ${ }^{1}$, BOĞAÇ A. ERGENE ${ }^{2}$, AND ATABEY KAYGUN ${ }^{3}$
}

\begin{abstract}
This article studies temporal variations in wealth levels and distribution in an Ottoman context during the eighteenth century. By analysing the probate estate inventories of the Muslim deceased in Kastamonu, located in north-central Anatolia, we demonstrate that real wealth levels generally declined over the course of the century. Our analysis also suggests that the economic conditions of poor men, if not women, deteriorated more so than those of the rich, fuelling growing inequality. The article explores the factors that contributed to these trends and discusses the relevance of our findings for long-term economic development patterns in the region from a comparative perspective.
\end{abstract}

Journal of Economic Literature Classification: D3, D6, E3, E6, I3, J1, N3, N9, O53, Keywords: wealth, inequality, war, weather, Ottoman Empire

\section{INTRODUCTION}

The economic history of the Ottoman Empire in the eighteenth century is not an exhaustively researched subject. Although we know more now about the general economic characteristics of the period compared with a few decades ago, the literature is still meagre on some very basic issues. Rare, in particular, are studies pertaining to the performance of the economy, social welfare, inequality, and how these varied over time. This is a major gap in the scholarship as information about such topics can provide clues about socio-economic variations among different segments of the population and long-term development patterns in the Middle East.

\footnotetext{
${ }^{1}$ Department of Economics, University of Connecticut.

${ }^{2}$ History Department, University of Vermont.

${ }^{3}$ Department of Mathematics and Computer Science, Bahçeşehir University.
} 
Using post-mortem estate inventories (sing. tereke) as found in court records, we demonstrate in this article how real wealth levels and distribution changed in Ottoman Kastamonu, a town located in north-central Anatolia, during the eighteenth century. The town resembled many provincial urban centres in Anatolia and the Balkans in terms of its size, and its economic and demographic characteristics. The article suggests that wealth accumulation patterns among men and women followed different trajectories and also reveals how human capital, wars, precipitation patterns and an empire-wide financial crisis affected the wealth levels of various socio-economic groups.

Our study is in line with recent scholarship in economic history that views modern economic growth in Europe as predating the industrial revolution. Advances in the commercial and agrarian sectors not only generated vibrant economic growth in select locations in the earlymodern age; they also sparked rapid industrialisation in later periods. ${ }^{1}$ This suggests that clear differences existed between regions that eventually became industrialised and those that did not even before the industrial revolution. In his recent book, Timur Kuran states that the economic gap between the Middle East and Western Europe widened after the mid-eighteenth century. ${ }^{2}$ If the origins of modern economic growth can be traced to the early-modern period, then the future economic gap between developed and underdeveloped regions must have begun to emerge before the 1750s. By examining the patterns and sources of wealth accumulation in a representative Middle East context, our study helps us test this hypothesis. In a period during which a few soon-to-be-industrialised regions in England and Holland were experiencing economic growth, we expect to observe stagnant or declining growth rates in Anatolian real wealth levels.

In this article, we also make observations on the relationship between wealth and 
inequality trends in an eighteenth-century Ottoman milieu. Since the formulation of the 'super Kuznets curve' by John Luiten van Zanden in 1995, the relationship between economic development and inequality in the pre-industrial era has received attention. ${ }^{3}$ Earlier, Simon Kuznets suggested that what he considered to be the first phase of the West European economic development between the late eighteenth and late nineteenth centuries was accompanied by increasing levels of inequality. ${ }^{4}$ However, if modern economic growth indeed began before industrialisation, we would expect to observe increasing inequality levels in developing regions earlier than Kuznets posited. Researchers who have found an association between economic development and increasing inequality in preindustrial settings usually point to wealth accumulation among richer groups (including potential investors and entrepreneurs), urbanisation, and the emergence of a specialised labour force with higher wage levels as the causes of economic stratification. ${ }^{5}$ An issue which has received less attention is how inequality levels may have fluctuated in stagnant or deteriorating preindustrial settings. Lee Soltow and Jan Luiten van Zanden suggested with reference to early-modern Overijssel (in Holland) that inequality levels remained stable when there was no growth. ${ }^{6}$ However, other researchers have demonstrated that inequality could increase even when preindustrial economies were not doing well. ${ }^{7}$ Clearly, more comparative research is required to better understand the relationship between growth and inequality before industrialisation. This article contributes to this aim.

\section{CONTEXT}

\subsection{Ottoman economy in the eighteenth century}

The literature on the economic history of the Ottoman Empire during the seventeenth and 
eighteenth centuries is dominated by discussions of the fiscal changes implemented during this period, particularly the increasing use by the government of tax farming for revenue collection in the rural economy and the institutionalisation of life-term tax farming (malikane) in $1695 .^{8}$ Although the shift from prebendal taxation ${ }^{9}$ to various forms of tax farming may well have influenced wealth accumulation and distribution (see below), there are many other factors relevant to the overall performance of the economy that have stimulated less interest among researchers.

Still, it is possible to identify in the literature two conflicting characterisations of the general state of the Ottoman economy in the eighteenth century. Until recently, it was common to view the eighteenth century as a period of general economic decline. Some researchers considered economic conditions to have been deteriorating because of financial problems associated with protracted warfare, powerful inflationary pressures, superior European competition, and an increasing tax burden on the population. Global trade patterns were seen as shifting from the Mediterranean to the Atlantic, with adverse consequences for Ottoman traders. Historians also observed a general sense of restlessness and insecurity in the countryside that forced peasants to migrate to urban centres and adversely affected agricultural production. ${ }^{10}$ However, in the last two decades or so, researchers have started to challenge this negative characterisation of the period. For example, Karen Barkey has suggested that the empire became 'more permeable to all kinds of trade with many European nations, and the empire-wide trade routes and commodity markets flourished, bringing more and more people into contact with one another. The result was a vast increase in the raw numbers of economic transactions. ${ }^{11}$ Whereas imports of luxury items (spices, drugs and gems) declined over the course of the century, exports of raw materials (grains, cotton, animal fibres and dyestuffs) and inter-regional exchange of 
manufactured goods produced for domestic markets expanded. ${ }^{12}$ Meanwhile, trade in new consumption goods such as coffee, sugar and tobacco brought many regions in the empire into greater contact with the global economy. In manufacturing, commercial expansion translated, if sporadically, into proto-industrial activities in rural areas. ${ }^{13}$

There are very few quantitative studies on the research area in the early-modern period and they too present conflicting results. On the one hand, there are studies that imply economic stagnation or deterioration; for example, the data of Süleyman Özmucur and Şevket Pamuk indicate that unskilled wages in Istanbul tended to decline during the eighteenth century. ${ }^{14}$ The observations made by Hülya Canbakal on the estate inventories of Ayntab, an important commercial centre in southern Anatolia, also suggest that the value of estates declined between the seventeenth and eighteenth centuries. ${ }^{15}$ On the other hand, there are also more positive assessments. Based on his examination of revenues generated by a sample of tax farms from various regions of the empire, Mehmet Genç has argued that the Ottoman economy expanded until the 1760s. ${ }^{16}$ Also in Vidin, a smaller but important commercial centre located in presentday Bulgaria, Nikolai Todorov has observed an increase in the number of wealthier estates and a decline in the number of poorer ones during the eighteenth century. ${ }^{17}$

In regard to changes in inequality levels, we know even less. ${ }^{18}$ It is possible that the spread of tax farming led to wealth transfers, as the process often encouraged exploitative revenue-extraction practices, according to some historians. ${ }^{19}$ It is, however, not clear to what extent the privatisation of state revenues through tax farming influenced overall inequality. ${ }^{20} \mathrm{In}$ addition, while the emergence of new commercial opportunities may have increased inequality in many locations, we lack any basis for informed speculation about these other places, which constituted the majority of the empire. Finally, although the literature anecdotally suggests that 
frequent wars during the eighteenth century and the increasing burden of regular and irregular taxation adversely affected economic conditions in general, no empirical study confirms this suggestion. In the analysis reported below we tackle these and other important problems.

\subsection{Kastamonu in the eighteenth century ${ }^{21}$}

The Kastamonu sub-province was composed of 34 districts (sing. kaza) in eighteenth century. ${ }^{22}$ The district of Kastamonu included the town of the same name, which was also the administrative centre of the sub-province, as well as the surrounding villages. Although no demographic sources, such as population surveys, are available for the eighteenth century, it is possible to gain an impression of the demographic features of Kastamonu from indirect indicators. Based on available tax records, Suraiya Faroqhi estimates the population of the town of Kastamonu to have been between 9,000 and 11,000 by the end of the sixteenth century. ${ }^{23}$ Since John Kinneir claims that the population was around 12,000 in 1814, the town does not seem to have grown much between the late sixteenth and early nineteenth centuries. ${ }^{24}$ In relative terms, then, the town of Kastamonu must have been a small- to medium-sized urban centre during our period.

Economic activities in the Kastamonu region in the eighteenth century resembled those in most locations in central and eastern Anatolia, consisting mainly of agriculture, animal husbandry and timber production. ${ }^{25}$ The major agricultural products of the region in the modern period are wheat, barley and rye. Fields that produced grain constituted more than 90 per cent of all agricultural lands in the mid-twentieth century and were concentrated in areas south of the İsfendiyar (Küre) Mountains, which hug the shoreline and separate the rain-receiving coastal areas from more the arid 'steppe-like' interior, where the town of Kastamonu is located. ${ }^{26}$ There 
is also potato and fruit production in the area. ${ }^{27}$ Given that the region did not experience radical agricultural transformations in the nineteenth and twentieth centuries, other than limited mechanisation, we assume that this picture also reflects the conditions of the eighteenth century. As elsewhere in Anatolia during this period, agricultural production was almost certainly concentrated in the hands of small peasants, who owned the means of production (primarily ploughs and oxen). The agricultural land was owned by the state, which allocated the rights of taxation to prebendal authorities or tax farmers.

In terms of manufacturing, sources indicate the existence of rope-making, linen-, silk-, cotton- and woollen-cloth production, cloth dying and tanning in the region. ${ }^{28}$ Copper mining and copperware production were also major activities. ${ }^{29}$ The town was situated on two alternative routes from Diyarbakır and Erzurum in eastern and southern Anatolia to Istanbul, and had commercial ties with urban centres in central Anatolia, mainly Kayseri and Ankara. ${ }^{30}$ We have no evidence, however, that major inter-regional and international trade activity existed in or around the town.

One can surmise that short- and longer-term tax farming became more prevalent during the eighteenth century. After the 1730s, the tax revenues of the sub-district were assigned as lifeterm tax farms (sing. malikane). ${ }^{31}$ The rights to collect taxes from specific revenue sources were probably subcontracted to members of the local elite as smaller tax farms. We also know that the cotton stamp tax, along with a tax on copper extraction, and one on timber production were also auctioned as tax farms. Determining the full extent of tax farming in other sectors, including agriculture, however, is difficult and requires further research. Finally, we should assume that the sophisticated credit relationships that were associated with the investment opportunities in tax farming underwent considerable growth. 
The absence of unique characteristics makes Kastamonu an ideal subject for our study. Similar to scores of out-of-the-way, minor towns in the provinces, it remained isolated from the major commercial developments that occurred in western Anatolia, the Levant and certain Balkan locations in the eighteenth century. In addition, the court records of the town, which also contain probate estate inventories, are quite complete relative to the size of the town. Recent quantitative research on the specific characteristics of the individual socio-economic groups that constituted the population of the town also provides us with a limited but valuable context in which to interpret our findings. ${ }^{32}$

\section{DATA}

In this study, we analyse about 2,200 estate inventories covering, with lapses, the 90-year period from 1713 to 1802. To prepare this dataset, we consulted the microfilm copies of Kastamonu sicils stored in the National Library of Turkey, in Ankara. The entire collection of Kastamonu sicils begins in 1684 and encompasses the time period between the late seventeenth and early nineteenth centuries. The earliest registers contain terekes only sporadically. Thus, we chose to start coverage at a later date, when the quality of documentation improves.

Prepared by court officials at the request of heirs, estate inventories provide detailed information about the wealth of an individual at the time of death, including a monetary appraisal of the cash, property and debt left behind..$^{33}$ They list the full names of the deceased, including the names of their fathers, honorific titles if they were male (which signified membership in the military or religious establishments), and the names and titles of their legal heirs. Typically, this information is followed by itemised lists and appraised values of all inherited (movable and 
immovable) property of the deceased, cash holdings, and outstanding loans to and from others at the time of death.

Terekes have limitations as historical sources. ${ }^{34}$ Tax farms and state-owned land (miri) to which individuals had usufruct rights are not included in these documents because they technically belonged to the state. Income and salaries generated by charitable endowments (evkaf), in which individuals frequently held hereditary positions, are also not reported. Moreover, terekes under-represent women, the rural population and the poor, and over-represent the elderly. Non-Muslim terekes are particularly rare (although they exist) because the court was obliged to divide estates according to Islamic rules of inheritance. Also, it is likely that many families tried to avoid the involvement of the court in the appraisal and division of estates since courts charged a fraction of the overall value of an estate as an 'inheritance tax' (resm-i klsmet), in addition to a number of lump-sum fees for its service. ${ }^{35}$ The appraisal and division of estates by the court were not legally required unless the heirs included orphans who had not yet attained their majority, but disagreements over inheritance shares often necessitated intervention by court officials. We also cannot be absolutely sure that the inventories accurately reflect the actual wealth of the deceased at the time of his or her death. Heirs often tried to conceal portions of their estates from court officials in order to reduce the 'inheritance tax'. There is also the issue of the reliability of the appraisals of estates since we cannot be sure of the motivations of the court officials preparing them - they may have inflated appraisals to increase their fees. Nevertheless, such problems are not specific to Ottoman estate inventories and they have not impeded the development of a rich economic-history literature for many Western contexts based on similar types of document.

We calculated the net value of individual estates by deducting the debts and outstanding 
obligations of the deceased from the monetary value of their properties and cash holdings. We divided our sample of estate inventories into two subsamples composed of male and female terekes and analysed them separately. This is because inventories belonging to women are severely under-represented and might suffer from a selection bias (see below). They are also likely to under-appraise the real value of wealth owned by testators since Muslim women tended to transfer their property to relatives long before death. ${ }^{36}$ After we trimmed the two datasets by 0.5 per cent from both tails in order to eliminate extreme outliers, some of which were based on suspicious value assessments, we ended up with a total of about 1,600 observations for men and 600 observations for women.

It is difficult to predict exactly what percentage of the deaths in Kastamonu is represented by the estate inventories. However, we can propose the following rough estimate if we assume (a) the annual crude death rate in our context to be around $0.035^{37}$ and (b) that the population of the town remained around 12,000 during the eighteenth century. Under these assumptions, the total number of deaths in the town over 90 years should be about 37,800 $(=0.035 \times 12,000 \times$ 90). Assuming that 15 per cent of these were non-Muslim, ${ }^{38}$ the total number of Muslim deaths must have been about 32,130. Since about 90 per cent of the estate inventories belonged to urban residents, roughly $1,440(=0.90 \times 1,600)$ male terekes and $540(=0.90 \times 600)$ female terekes must have belonged to those who lived within the boundaries of the town. These figures would indicate that our subsample of male terekes represents about $9(=1,440 /(32,130 \times 0.5))$ per cent of the male deaths and our subsample of female terekes represents about $3(=540 /(32,130 \times 0.5))$ per cent of female deaths. The rates of representation improve towards the end of our period since court records contain more terekes in later years.

Finally, to remove price effects from the data, we deflated the nominal values in estate 
inventories by using the consumer price index calculated by Özmucur and Pamuk for Istanbul. ${ }^{39}$

\section{ANALYSIS}

In Table $1<<$ insert Table 1 near here >>, we provide the real wealth averages of different wealth segments for men and women in nine 10-year periods. For both men and women the numbers of estates in the sample for the first four periods are noticeably smaller than the numbers of estates included in the latter five. This situation might indicate a sampling incongruity between the earlier and the later periods, if the representation of estates that belonged to different economic groups varied across sub-periods. There is no direct way to determine if such an incongruity exists in our dataset. However, based on earlier research on eighteenth-century Kastamonu, we know that significant wealth variations existed between the elite title-holders (individuals with titles ' $A \breve{g} a$ ' and 'Efendi'), who constituted the richest and most privileged groups, and the rest of society. ${ }^{40}$ Since we do not observe a major discrepancy between the proportions of elite-owned estates in the two sub-periods (15.6 per cent for 1713-1752; 16.5 per cent for 1753-1802) in male terekes, we assume that the smaller number of observations made for the first 40 years are not indicative of a sampling problem in the subsample for men. On the other hand, while the proportion of females in our sample who were the daughters of elite title-holders is 16 per cent for the period between 1713 and 1752, this proportion is 9 per cent for the period between 1753 and 1802. This finding strengthens our suspicion that our collection of female terekes suffers from a sampling bias.

The information presented in Table 1 suggests that the wealth averages for men and women tended to decline between 1713 and 1802. The short periods of upturn notwithstanding, 
the declining trends suggest that the eighteenth century was an era of general economic deterioration and impoverishment in a commercial and industrial backwater such as Kastamonu.

Among men, the declining trends in real wealth levels appear to be more pronounced for poorer groups. Whereas the average wealth of the richest quartile (1st quartile) declined only about 5 per cent per decade, the average wealth of the poorest quartile (4th quartile) dropped by about 14 per cent. Consequently, the shares of the richest groups steadily increased between the 1730s and the 1780s. The shifts experienced in the wealth shares of different groups are also visible in the Gini coefficients, a measure of overall inequality in wealth distribution (see Table $2<<$ insert Table 2 near here $>>$ ). For the 1780 s we calculated the Gini coefficient as 0.68 , about 0.11 to 0.17 points higher than the values we found for the 1710 s and the 1720 s. Although we observe an improvement in distribution of wealth during the last two decades of the eighteenth century, inequality was still greater than had been in the 1710 s and 1720 s. ${ }^{41}$

Our calculations based on female terekes indicate a generally more equal wealth distribution compared with men. However, the inequality levels of women also appear to have increased in the second half of the eighteenth century. ${ }^{42}$ Thus, male- and female-owned terekes collectively suggest that Kastamonu became more unequal during our era.

Unfortunately, the economic history of the region reveals little about how private sources of wealth accumulation might have allowed the rich to better protect their wealth compared with the rest of society. However, the fiscal history of the period provides clues in this regard. According to Genç, the malikane system provided an opportunity to accumulate wealth for those who were rich enough to invest in lucrative revenue sources for most of the eighteenth century. The calculations made by Genç indicate that between 1720 and 1750 the yearly average profit generated by malikanes was as high as 35 to 40 per cent of the lump-sum payments made at the 
time of contract. Between 1751 and 1771 that rate varied between 25 and 35 per cent. ${ }^{43}$ Also, Svetla Ianeva has observed that tax farming was potentially a more profitable investment opportunity than regional and long-distance trade in mid-nineteenth-century Rumelia, a milieu that was certainly much more commercialised and better connected to international markets than eighteenth-century Kastamonu. ${ }^{44}$ Since it is reasonable to assume that the wealthiest inhabitants of Kastamonu, more so than the rest of the community, invested in or became associated with the expanding tax-farming system as contractors, subcontractors or local financiers, it would make sense that they benefited more from this profitable endeavour than others. ${ }^{45}$ It is also possible that it was these groups that benefited most from the opportunities associated with the expansion of credit networks, if such a development did indeed take place in Kastamonu. ${ }^{46}$

In addition, we should also remember that provincial officials who had tax-collection privileges tended to be wealthier than the rest of the society and, thus, it is more likely that they are included in the first quartile in our sample. These individuals had some ability to unload their economic burdens onto taxpayers. Indeed, the literature indicates that duplicitous, excessive and extra-legal taxation was common in the eighteenth century. ${ }^{47}$ If the same also took place in Kastamonu, our findings may indicate that the relative ability of the wealthiest groups to maintain their wealth levels came, at least to some undeterminable extent, at the expense of the lower classes.

Overall, our findings indicate that increasing levels of inequality accompanied general economic deterioration. In this sense, what we observe in eighteenth-century Kastamonu resembles the economic trends in eighteenth-century Flanders and seventeenth-century northern Italian towns, more than those in, for example, northern Holland in the early-modern period, where growth fuelled inequality. ${ }^{48}$ Both Wouter Ryckbosch and Guido Alfani use their findings 
to question the widely assumed Kuznetsian association between inequality and economic development in the early-modern period. Although it is likely that the factors responsible for increasing inequality in Flanders, northern Italy and Kastamonu were different, our findings, like theirs, indicate that rising wealth disparity could take place in stagnant or deteriorating economic conditions. $^{49}$

On the other hand, our calculations confirm the validity of another Kuznetsian expectation in the Ottoman context: inequality levels in Kastamonu generally appear to have been lower than those calculated for larger urban centres in the Ottoman Empire. By using probate estate inventories, Colette Establet, Jean-Paul Pascual and André Raymond calculated the Gini coefficients for early eighteenth-century Damascus and Cairo, respectively, as 0.74 and 0.81 , values that are larger than our estimates of 0.62 ( 0.60 for men, 0.46 for women) for the period between 1713 and 1749, 0.67 (0.66 for men, 0.54 for women) for the period between 1850 and 1802, and 0.66 (0.65 for men, 0.53 for women) for the entire eighteenth century. ${ }^{50}$ Also, while Canbakal calculates the wealth shares of the top 1, 10 and 20 per cent of tereke-

owners in eighteenth-century Ayntab as 19, 70 and 83 per cent, respectively, ${ }^{51}$ the corresponding values in our sample are 16, 55 and 70 per cent (15, 52 and 69 per cent for men; 10, 41 and 58 per cent for women).

\subsection{Determinants of wealth}

For a regression analysis of determinants of wealth, we supplement information from terekes with available data on a number of factors that would be expected to affect levels of wealth during this period. One explanatory variable, constructed from information on the honorary titles of individuals as recorded in terekes, is a proxy for human capital. Using all existing information 
on adverse shocks, we also constructed a second group of variables to examine the way these shocks influenced wealth. More specifically, the regression analysis includes the following independent variables:

Elite titles as a proxy for military and religious educational attainment. This variable, used in the regressions for men, represents the proportions of estates that belonged to elite military and religious title-holders ('A individual group-based samples. The highest-ranking military-administrative officials in Kastamonu, such as governors, sub-governors and military commanders, all carried the military title ' $A \breve{g} a$ ', a designation that presumably required years of training, service and experience in military service and/or provincial administration. The highest-ranking religious- and legal-status holders, such as magistrates (qadis) and jurisconsults (müftis), were 'Efendis', a title associated with formal and informal education and proficiency in the religious and legal sciences. ${ }^{52}$ We include this variable in the regressions to determine the relationship between human capital and wealth. $^{53}$

Including this variable in our analysis also helps us to control for the potential sampling problem noted earlier, that is, the possibility that variations in wealth levels over time could be caused by changes in the composition of individuals included in tereke data. Although women did not use military and religious titles, it is likely that those who were related to elite titleholders were relatively wealthy. Thus, in our analysis for women, we control for variations in the rates of women related to elite title-holders as daughters and wives.

Post-1767. This is a dummy variable that measures the impact of the severe financial crisis after 1767. Historians indicate that fiscal circumstances in the empire first deteriorated with the Ottoman-Russian wars of 1768-1774 and became even worse when the Ottomans entered 
another war in 1787, this time against both Russia and Austria. In order to close the budget gap that emerged during the last three decades of the eighteenth century, the government increased revenue extraction by imposing a variety of new taxes. ${ }^{54}$ For these reasons, we suspected that wealth averages might have undergone a downward structural shift after 1767.

Dummies associated with Incidents of war. These variables measure the relationship between wealth and war. The relationship between war and wealth levels has not been empirically investigated in Ottoman historiography until now. However, some historians have proposed a negative association between periods of war and overall economic performance. ${ }^{55}$ One oft-quoted study on this topic is the analysis by Genç of the possible impact of war conditions on Ottoman industrial production in the eighteenth century, ${ }^{56}$ which suggested that wartime needs and governmental policies to satisfy them must have led to industrial decline and economic contraction. According to Genç, wartime taxation and the practice of the government of acquiring wartime supplies and services at artificially low, fixed prices must have drained available capital and labour, and reduced the supply of industrial raw materials, grains and livestock for profit-oriented endeavours.

More recently, Rhoads Murphey has questioned the claims made by Genç about the ability of the government to purchase war supplies at low or fixed prices and the responsiveness of the Ottoman economy to wartime needs. Instead, he has proposed a positive link between war and trade. ${ }^{57}$ According to Murphey, wartime allowances and cash bonuses that troops received must have not only stimulated the local economies where soldiers were stationed during times of conflict but also trickled down to and had an impact on their own regions after they returned home.

It is impossible to isolate the economic impact of the wartime fiscal policies of the 
imperial government from the effects of any other war-induced economic or financial stimuli. Therefore, our analysis shows simply the correlation between incidents of war and wealth averages. To prepare the War proxy used in the analysis, we identified the years during which the Ottomans engaged militarily with other major Euro-Asian powers using chronologies provided by Halil İnalcık and Donald Quataert, and Virginia Aksan. ${ }^{58}$ This proxy, it should be noted, does not take into consideration the differences in the intensity of individual wars.

Dummies associated with Weather patterns. Given the primarily agricultural basis of the economy in eighteenth-century Kastamonu, it is reasonable to suggest that weather patterns influenced wealth levels. In our analysis, we examine the nature of the relationship between wealth levels and dummy variables representing 'Dry' and 'Wet' years. The precipitation data that we utilise in our analysis come from a dendro-climatology study published by Ünal Akkemik, Nesibe Dağdeviren and Aliye Aras. ${ }^{59}$

Time. Finally, we use this proxy to demonstrate how wealth levels were inclined to move on a yearly basis, when we kept other variables constant. This is an important variable because it reveals how trends in real wealth averages would have developed over time if they had not been affected by external shocks such as war, weather patterns and financial crises, and if the sampling problem associated with the over- or under-representation of elite-owned (in the case of women, elite-related) estates in yearly samples were eliminated.

The dependent variables in the regression models presented in Tables 3 and 4 are annual real-wealth averages for specific gender and wealth groups. These regressions include war and weather dummies with and without lags.

Our results for men indicate that the post-1767 crisis had a noticeable negative impact on the welfare of the inhabitants of Kastamonu. The positive coefficient estimated for elite title- 
holders is not surprising given what we know about this group, although our model failed to generate a statistically significant result. The analysis also reveals that the impact of wars on wealth became statistically apparent two years after the event and was positive.

There is empirical evidence to suggest a positive association between precipitation levels and agricultural productivity where grain production and dry farming are prevalent, as in Kastamonu. ${ }^{60}$ This is why it is not surprising to observe a positive relationship between higher levels of rainfall and male real wealth averages. It is, however, difficult to explain the positive association that we observe between drought years and wealth. Although there is no way to be sure, the positive coefficient estimated for 'Dry’ might represent the price effects generated by drought periods on the value assessments for estate inventories. It is possible that drought conditions (or even expectations of drought) led to general increases in local price levels. Since droughts are often region-specific, the Istanbul-based consumer price index we used to deflate wealth observations may have failed to capture the actual price fluctuations in Kastamonu during drought periods. Therefore, it may be supposed that the appraisals of inherited estates were influenced by such price increases in dry years. This reasoning would explain why an immediate positive association between dry years and wealth averages is observed, since a drastic change in price levels should have an immediate impact on value assessments.

Finally, our estimation for Time in the regression for men indicates that when we control for the effects of external shocks generated by war incidents, weather patterns, the post-1767 crisis and the proportion of elite-owned estates in our sample, the trend-line for overall realwealth averages had a positive and relatively large, if statistically insignificant, slope during the eighteenth century. ${ }^{61}$

The regression for women in Table $3<<$ insert Table 3 near here $>>$ reveals different 
dynamics, though we should remind the reader that they are based on a significantly smaller sample and thus should be interpreted cautiously. According to our results, marriage to an elite title-holder is an indicator of relative affluence for women. The real wealth of women appears to be insensitive to the post-1767 economic crisis, wars or elevated precipitation. ${ }^{62}$ However, periods of drought seem to have positively influenced the wealth of women, just as was observed for men, although not quite so immediately. Finally, the Time coefficient calculated for women is consistent with the negative and statistically significant slope estimate for the female population as a whole (Table 1$)$.

Table $4<<$ insert Table 4 near here $>>$ presents the regression analyses for different male wealth groups. ${ }^{63}$ One noticeable inter-group disparity among men pertains to how different segments experienced the economic impact of the post- 1767 crisis. Our estimations indicate that the crisis affected the wealthiest groups most severely, while its impact on the very poor was statistically insignificant. This finding is consistent with what historians have said about the financial circumstances after 1767 and how the imperial government attempted to cope with them. Although lower classes were also pressured by tax demands, historians make special mention of the ways in which the wealthy were financially squeezed by the government. The malikane-holders were often required to pay additional taxes such as cebelü bedeliyesi, equivalent to 15 per cent of the initial lump sum that they paid for their malikanes, and to make frequent non-voluntary contributions to the treasury. ${ }^{64}$ Also, in the 1780 s, confiscation (müsadere) of the private property of affluent government officials became common. ${ }^{65}$ Finally, according to Genç, the revenues generated by the malikanes fell significantly after the 1770 s, ${ }^{66}$ which must have hurt the economic conditions of the wealthy even further.

Wars seem to have influenced the wealth levels of the first, third and fourth quartiles in 
similar ways. For the second quartile, however, our regressions produced statistically insignificant coefficients. ${ }^{67}$ The years of above-average precipitation had a positive and statistically significant impact on the wealth levels of the top 10 per cent and the first quartile. The likelihood that a relatively large proportion of the estates included in the first quartile belonged to tax farmers or individuals with tax-collection privileges might explain why we found a large positive coefficient for this group; in periods of favourable weather conditions, revenue collection and tax extraction from agrarian sources must have been easier. ${ }^{68}$ It is, however, difficult to explain why we fail to find a significant relationship between wealth and wet years for other groups. ${ }^{69}$

As discussed, it is not clear to what extent the coefficients calculated for dry years reflect the relationship between this variable and real wealth levels. The uncertainty regarding the interpretation of these coefficients makes it difficult to assess precisely how the dry years influenced welfare in Kastamonu. ${ }^{70}$ However, our estimations indicate that drought periods inflicted the greatest suffering on the poorest quartile.

Finally, the coefficients estimated for Time suggest that, if all other factors had held constant, the wealth averages of different groups would have moved differently, which is an important finding for the general concerns of this article. ${ }^{71}$ The positive coefficients of Time for the top 10 and 25 per cent of the male population indicate that these groups would have become richer by the end of the century if their assets had not been affected by the shocks caused by war, weather patterns and the post-1767 crisis. On the other hand, the poorest quartile demonstrated a tendency to become even poorer over time.

The results suggest a potential for wealth accumulation for the rich. Given what we know about the general economic conditions of the period, it is possible to associate this potential for 
wealth accumulation with increasing short- and long-term tax-farming opportunities, ${ }^{72}$ the spread of sophisticated credit networks, and the disposition of government functionaries to over-tax taxpayers in their jurisdictions, all tendencies that have been observed in many other contexts by a multitude of researchers. Less clear is why the real wealth levels of the poor were inclined to decline in the same period. Over-taxation, an endemic problem in the eighteenth century, must have threatened their economic well-being but it is not known to what extent taxpayers were affected by this. Historians have also discussed the exploitative nature of intensive tax farming and sub-farming, but the relationship between tax farming and wealth transfers between the upper and lower classes has yet to be empirically demonstrated.

\section{CONCLUSION}

Based on information gathered from probate estate inventories, this article has explored temporal shifts in the levels and distribution of real wealth in eighteenth-century Kastamonu. The analyses revealed that while wealth levels declined over time, wealth distribution also deteriorated. From a comparative perspective, our findings are important for two reasons. First, the lack of economic growth in eighteenth-century Kastamonu, a location that failed to experience modern economic growth until very recently, is consistent with the suggestion made by van Zanden that the symptoms of modern economic underdevelopment can be observed as early as the earlymodern period. Second, our results indicate that levels of inequality could become worse in preindustrial milieus even when the prevailing economy shrank.

Our results also identified several factors influencing wealth levels in Kastamonu and how these effects could vary among different segments of society. Although association with 
elite status indicated relative affluence for women and possibly for men, wars, economic crises and weather incidents influenced the wealth levels of these groups in dissimilar fashions. We also observed that the post-1767 economic crisis affected rich men more than the poor, that high levels of precipitation generated positive wealth effects for the rich, that droughts constituted a significant economic challenge for the poor, and that most male wealth groups became better off

after wars. Finally, the article revealed that without the shocks associated with wars, precipitation patterns and financial crises, the richest men would have accumulated wealth and the poorest ones would have become even poorer over the course of the eighteenth century.

Placed in the context of existing literature on the historical conditions of the era, our results provide evidence for some of the arguments about the effects on wealth of the privatisation of government-owned revenue sources, expanding sophisticated credit networks and the ability and inclination of provincial authorities and power-holders to transfer their economic burdens to taxpayers. Further research on different provincial contexts is necessary to test and, hopefully, substantiate our findings.

\section{ACKNOWLEDGEMENTS}

The authors are grateful to Elaine McCrate, Alix Heintzman and Charlotte Weber for their assistance and support. We also thank the editors of Continuity and Change and three anonymous referees for useful criticisms and suggestions. 
TABLE 1

Average real wealth in eighteenth-century Kastamonu, by 10-year period (in guruş) ${ }^{a}$

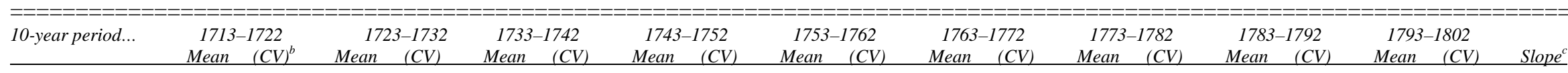

\section{Men}

Top $10 \%$

1st $25 \%$

2nd 25\%

3rd 25\%

4th $25 \%$

Overall average

$\begin{array}{cccccc}3,591.8 & (0.57) & 2,000.8 & (0.35) & 4,423.6 & (0.39) \\ 2,224.1 & (0.81) & 1,437.3 & (0.49) & 2,910.1 & (0.61) \\ 581.2 & (0.15) & 549.4 & (0.19) & 784.2 & (0.26) \\ 309.0 & (0.22) & 266.7 & (0.25) & 317.1 & (0.24) \\ 137.1 & (0.37) & 88.3 & (0.52) & 91.1 & (0.77) \\ & & & & & \\ 810.1 & (1.49) & 584.9 & (1.07) & 1,037.2 & (1.39) \\ 85 & & 73 & & 82 & \end{array}$

$\begin{array}{cccc}2,351.8 & (0.63) & 4,170.6 & (0.92) \\ 1,420.4 & (0.88) & 2,398.2 & (1.20) \\ 346.5 & (0.26) & 481.8 & (0.28) \\ 161.9 & (0.26) & 203.1 & (0.23) \\ 67.7 & (0.39) & 71.5 & (0.49) \\ & & & \\ 502.2 & (1.65) & 790.8 & (2.17) \\ 111 & & 271 & \end{array}$

$\begin{array}{cc}2,928.7 & (0.87) \\ 1,620.4 & (1.21) \\ 341.8 & (0.22) \\ 140.2 & (0.26) \\ 51.9 & (0.46) \\ & \\ 537.9 & (2.16) \\ 281 & \end{array}$

$\begin{array}{cc}3,008.1 & (0.50) \\ 1,716.9 & (0.86) \\ 299.2 & (0.34) \\ 129.7 & (0.20) \\ 46.9 & 0.48) \\ & \\ 547.0 & (1.82) \\ 213 & \end{array}$

$2,260.5(0.69)$ $1,249.7 \quad(1.03)$

$293.1 \quad(0.30)$

$121.0 \quad(0.28)$

$40.5 \quad(0.49)$

$428.1 \quad(1.88)$
198

198

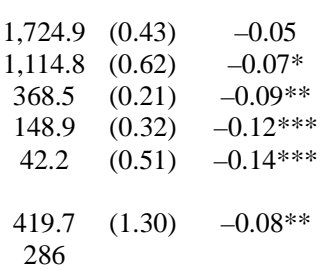

286

\section{Women}

\section{Top 10\%}

1 st $25 \%$

2nd 25\%

3rd 25\%

4th 25\%

$\begin{array}{cccc}693.3 & (0.02) & 1,544.9 & (1.29) \\ 595.9 & (0.23) & 1,018.5 & (1.55) \\ 245.0 & (0.11) & 171.9 & (0.18) \\ 136.8 & (0.31) & 73.6 & (0.24) \\ 57.0 & (0.11) & 35.5 & (0.41)\end{array}$

\section{$493.3 \quad(0.45)$}

$\begin{array}{ll}382.0 & (0.49) \\ 161.6 & (0.18)\end{array}$

$\begin{array}{ll}74.5 & (0.29) \\ 26.6 & (0.73)\end{array}$

\section{$681.2 \quad(0.27)$}

$\begin{array}{ll}495.7 & (0.41) \\ 189.6 & (0.20)\end{array}$

$\begin{array}{ll}189.6 & (0.20) \\ 101.3 & (0.30)\end{array}$

$920.1 \quad(0.63)$

$\begin{array}{ll}578.6 & (0.81) \\ 163.7 & (0.20) \\ 88.0 & (0.22)\end{array}$

$633.2 \quad(0.29)$

$\begin{array}{ll}427.2 & 0.51) \\ 149.9 & (0.16)\end{array}$

$\begin{array}{ll}398.9 & (0.56) \\ -118.8 & (0.77)\end{array}$

$398.9 \quad(0.77)$

$\begin{array}{cc}118.8 & 0.20) \\ 76.0 & (0.13)\end{array}$

$\begin{array}{llllllll}36.8 & 0.47) & 33.2 & (0.38) & 37.5 & (0.45) & 41.2 & (0.34)\end{array}$

$639.3 \quad(0.44)$

$\begin{array}{ll}410.6 & (0.68) \\ 124.8 & (0.22)\end{array}$

$\begin{array}{cc}124.8 & (0.22) \\ 67.3 & (0.20)\end{array}$

$\begin{array}{ll}67.3 & (0.20) \\ 32.7 & (0.37)\end{array}$

$617.0 \quad(0.42) \quad-0.13^{* *}$

$403.0 \quad(0.62) \quad-0.05$

$133.8 \quad(0.24) \quad-0.07^{\#}$

Overall average

$258.7 \quad(0.86)$

$161.2 \quad(1.01) \quad 205.5 \quad(0.98)$

$215.9 \quad(1.47)$

$176.4 \quad(1.06)$

$160.2 \quad(1.31)$

$158.8 \quad(1.28)$

$\begin{array}{ll}69.9 & (0.18) \\ 33.8 & 0.36)\end{array}$

$-0.08$

${ }^{\mathrm{a}}$ To deflate nominal wealth averages, the consumer price index calculated by

Özmucur and Pamuk for Istanbul was used (base period: 1713); see Süleyman Özmucur and Şevket Pamuk, 'Real wages and the standards of living in the Ottoman Empire, 1469-1914', Journal of Economic History 62, 2 (2002), 293-321, here 301.

${ }^{b}$ Coefficients of variation (CV) are given in parentheses.

c 'Slope' indicates the slope of the trend-line of respective wealth averages in the natural logarithmic scale.

$$
\text { Significance: }{ }^{\#} 15 \% \text {, * 10\%, ** 5\%, *** } 1 \% \text {. }
$$


TABle 2

Wealth shares and Gini coefficients in eighteenth-century Kastamonu

10-year periods $\cdots 1713-1722$

1723-1732

$1733-1742$

1743-1752

1753-1762

1763-1772

$1773-1782$

1783-1792

1793-1802

Slope S $^{a}$

\section{Men}

\begin{tabular}{|c|c|c|c|c|c|c|c|c|c|c|}
\hline Top 10\% & 46.9 & 37.5 & 46.8 & 50.6 & 54.5 & 56.2 & 56.8 & 53.3 & 41.7 & 0.02 \\
\hline 1st $25 \%$ & 67.8 & 60.6 & 71.9 & 71.4 & 76.1 & 75.0 & 78.1 & 73.7 & 66.9 & 0.01 \\
\hline 2nd $25 \%$ & 18.6 & 24.4 & 18.4 & 17.4 & 15.3 & 16.1 & 13.9 & 16.9 & 21.8 & -0.02 \\
\hline $3 r d 25 \%$ & 9.4 & 11.2 & 7.5 & 7.8 & 6.4 & 6.5 & 5.9 & 7. 0 & 8.8 & $-0.04^{\#}$ \\
\hline 4 th $25 \%$ & 4.2 & 3.7 & 2.2 & 3.4 & 2.3 & 2.4 & 2.1 & 2.4 & 2.5 & $-0.06 * *$ \\
\hline Gini coefficient & 0.57 & 0.51 & 0.61 & 0.61 & 0.67 & 0.67 & 0.68 & 0.65 & 0.58 & $0.01^{\#}$ \\
\hline \multicolumn{11}{|l|}{ Women } \\
\hline Top 10\% & 40.2 & 71.3 & 36.7 & 33.8 & 44. 4 & 38.7 & 42.0 & 45.3 & 42.2 & -0.02 \\
\hline 1st $25 \%$ & 57.6 & 78.4 & 56.9 & 59.1 & 67.0 & 61.7 & 63.7 & 64.6 & 62.5 & 0.00 \\
\hline 2nd $25 \%$ & 23.7 & 13.2 & 28.1 & 24.5 & 19.0 & 20.8 & 18.1 & 19.6 & 21.4 & 0.00 \\
\hline $3 r d 25 \%$ & 13.2 & 5.7 & 11.1 & 12.1 & 10.2 & 12.0 & 11.6 & 10.6 & 10.8 & 0.02 \\
\hline 4 th $25 \%$ & 5.5 & 2.7 & 4. 0 & 4.4 & 3.8 & 5.4 & 6.6 & 5.1 & 5.2 & 0.05 \\
\hline Gini coefficient & 0.44 & 0.71 & 0.48 & 0.49 & 0.56 & 0.49 & 0.51 & 0.53 & 0.52 & 0.00 \\
\hline
\end{tabular}

a 'Slope' indicates the slope of the trend-line of respective values in the natural logarithmic scale over nine decades, except for the Gini coefficients.

${ }^{b}$ The 'slope' for the Gini coefficient values refers to the slopes of the trend-lines of these values, untransformed.

Significance: ${ }^{\#} 15 \%$, * 10\%, ** 5\%. 
TABLE 3

Determinants of annual real-wealth averages, for men and women in eighteenth-century Kastamonu ${ }^{a}$

Men

\begin{tabular}{|c|c|c|c|c|}
\hline Intercept & 6. $081 * * *$ & $(0.233)$ & 5. $724 * * *$ & $(0.215)$ \\
\hline Time & 0.007 & $(0.005)$ & $-0.010 * *$ & $(0.005)$ \\
\hline Post-1767 & $-0.697 * *$ & $(0.260)$ & 0.329 & $(0.223)$ \\
\hline Proportions of elite title-holders & 0.262 & $(0.685)$ & & \\
\hline Proportions of women with elite fathers & & & 1.975 & $(1.765)$ \\
\hline Proportions of women with elite husbands & & & $3.216 *$ & $(1.955)$ \\
\hline War & -0.103 & $(0.155)$ & -0.134 & $(0.145)$ \\
\hline War_1-year lag & 0.173 & $(0.196)$ & -0.009 & $(0.180)$ \\
\hline War_2-year lag & $0.306 *$ & $(0.166)$ & 0.137 & $(0.166)$ \\
\hline Dry & $0.373 * *$ & $(0.166)$ & -0.102 & $(0.205)$ \\
\hline Dry_1-year lag & 0.315 & $(0.225)$ & $0.347 *$ & $(0.178)$ \\
\hline Dry_2-year lag & -0.221 & $(0.185)$ & 0.111 & $(0.210)$ \\
\hline Wet & 0.007 & $(0.218)$ & 0.283 & $(0.200)$ \\
\hline Wet_1-year lag & 0.040 & $(0.170)$ & -0.163 & $(0.187)$ \\
\hline Wet_2-year lag & $0.549 * * *$ & $(0.191)$ & 0.082 & $(0.181)$ \\
\hline$R^{2}$ & 0.52 & & 0.46 & \\
\hline$F$ & 3. $315 * * *$ & & 2. $063 * *$ & \\
\hline$n$ & 50 & & 45 & \\
\hline
\end{tabular}

${ }^{a}$ Standard errors in parentheses. Dependent variable is the natural logarithm of overall wealth average/year. Years with less than four wealth observations are omitted.

Significance: * 10\%, ** 5\%, *** $1 \%$. 
TABLE 4

Determinants of group-based annual real wealth averages for men ${ }^{\mathrm{a}}$

\begin{tabular}{|c|c|c|c|c|c|}
\hline & Tор 10\% & 1st (Richest) 25\% & 2nd $25 \%$ & $3 r d 25 \%$ & 4th (Poorest) 25\% \\
\hline Intercept & $7.005 * * *(0.366)$ & $6.751 * * *(0.318)$ & $6.050 * * *(0.174)$ & $5.446 * * *(0.184)$ & $4.817 * * *(0.184)$ \\
\hline Time & $0.014 * * \quad(0.007)$ & $0.009 * \quad(0.005)$ & $-0.001 \quad(0.004)$ & $-0.005 \quad(0.004)$ & $-0.013 * * *(0.004)$ \\
\hline Proportions of elite title-holders & $(0.347)$ & $(0.501)$ & $(0.380)$ & $(0.486)$ & $(0.563)$ \\
\hline War & $-0.095 \quad(0.230)$ & $(0.180)$ & $-0.002 \quad(0.122)$ & $-0.036 \quad(0.130)$ & $-0.062 \quad(0.131)$ \\
\hline War_1-year lag & $-0.150 \quad(0.322)$ & $(0.235)$ & $(0.156$ & $(0.166)$ & $-0.125 \quad(0.166)$ \\
\hline Dry & $0.624 * * \quad(0.277)$ & $0.473 * \quad(0.237)$ & $(0.148)$ & $0.288 * \quad(0.153)$ & $(0.153)$ \\
\hline Dry_1-year lag & $(0.376)$ & $(0.307)$ & $-0.006 \quad(0.211)$ & $-0.219 \quad(0.218)$ & $-0.382 * \quad(0.214)$ \\
\hline Dry_2-year lag & $-0.127 \quad(0.302)$ & $-0.147 \quad(0.236)$ & $-0.131 \quad(0.162)$ & $-0.256 \quad(0.172)$ & $-0.252 \quad(0.172)$ \\
\hline Wet & $0.023 \quad(0.375)$ & $(0.267)$ & $(0.182)$ & $-0.007 \quad(0.212)$ & $(0.192)$ \\
\hline Wet_1-year lag & $-0.075 \quad(0.256)$ & $-0.008 \quad(0.201)$ & $(0.135)$ & $(0.142)$ & $(0.143)$ \\
\hline Wet_2-year lag & $0.973 * * * \quad(0.278)$ & $0.765 * * * \quad(0.220)$ & $(0.148)$ & $(0.155)$ & $(0.156)$ \\
\hline$R^{2}$ & 0.48 & 0.51 & 0.59 & 0.64 & 0.65 \\
\hline$n$ & 43 & 44 & 44 & 44 & 44 \\
\hline
\end{tabular}

${ }^{a}$ Standard errors in parentheses. Dependent variable is the natural logarithm of segment wealth. In quartile-based regressions, years that have less than eight wealth observations are omitted. In the regression for the top 10 percent, years with less than 10 observations are omitted.

Significance: * $10 \%$, ** 5\%, *** $1 \%$. 


\section{ENDNOTES}

${ }^{1}$ See, for example, J. L. Van Zanden, 'Tracing the beginning of the Kuznets curve: Western Europe during the early modern period', Economic History Review 48, 4 (1995), 643-64; K. G. Persson, Pre-industrial economic growth (Oxford, 1988); N. F. R. Crafts, British economic growth during the industrial revolution (Oxford, 1985); Rondo E. Cameron, A concise economic history of the world (Oxford, 1989).

2 Timur Kuran, The long divergence: how Islamic law held back the Middle East (Princeton, 2011), 3-4.

${ }^{3}$ Van Zanden, 'Kuznets curve’; Lee Soltow and Jan Luiten van Zanden, Income and wealth inequality in the Netherlands, 16th-20th century (Amsterdam, 1998); P. Lindert, 'Three centuries of inequality in Britain and America', in F. Bourguignon and A. B. Atkinson eds., Handbook of income distribution, vol. 1 (Amsterdam, 2000), 167-216; R. C. Allen, 'The great divergence: wages and prices from the Middle Ages to the First World War’, Explorations in Economic History 38 (2001), 411-47; Philip T. Hoffman, David S. Jacks, Patricia A. Levin and Peter H. Lindert, 'Real inequality in Europe since 1500', Journal of Economic History 62, 2 (2002), 322-55; C. Santiago-Caballero, 'Income inequality in central Spain, 1690-1800’, Explorations in Economic History 48, 1 (2011), 83-96; Hülya Canbakal, 'Reflections on the distribution of wealth in Ottoman Ayntab’, Oriens 37 (2009), 237-52.

${ }^{4}$ Simon Kuznets, ‘Economic growth and income inequality’, American Economic Review 45, 1 (1955), 1-28, here 19.

${ }^{5}$ Van Zanden, 'Kuznets curve’; Lindert, ‘Three centuries'.

${ }^{6}$ Soltow and van Zanden, Income and wealth inequality, ch. 4.

${ }^{7}$ Wouter Ryckbosch, 'Scarcity and prosperity before the Industrial Revolution: household wealth in the southern low countries: Aalst, 17th-18th centuries' (unpublished paper presented at N.W. Posthumous Conference, Antwerp, 12-13 May 2011), available on http://webhost.ua.ac.be/nwpc2011/papers/RP2_Ryckbosch.pdf; G. Alfani, 'Wealth inequalities and population dynamics in early modern northern Italy’, Journal of Interdisciplinary History 11 (2010), 513-49.

${ }^{8}$ In the Ottoman context, tax farming refers to the farming of public revenue sources, including agricultural taxes and taxes associated with manufacturing, customs, mining and specific services. Individuals who won the right to tax these sources in public auctions paid the state a lump sum and fixed installments for the duration of their contracts. Between the fifteenth and seventeenth centuries tax farm contracts did not extend beyond five years. Life-term tax farming was introduced at the end of the seventeenth century, as a result of increasing government demand for funds due to frequent wars and financial crises during this period.

${ }^{9}$ Under the prebendal system, local cavalry forces collected land taxes, mostly in kind, as compensation for military service during the times of war and for maintaining order in their locales in peacetime. 
${ }^{10}$ B. Lewis, 'Some reflections on the decline of the Ottoman Empire', Studia Islamica 9 (1958), 111-27; C. Issawi, The economic history of the Middle East, 1800-1914 (Chicago, 1966); Y. Özkaya, XVIII. Yüzyılda Osmanlı Kurumları ve Osmanlı Toplum Yaşantısı (Ankara, 1985), ch. 8; A. Tabakoğlu, Gerileme Dönemine Girerken Osmanlı Maliyesi (Istanbul, 1985), 205-41.

${ }^{11}$ Karen Barkey, Empire of difference: the Ottomans in comparative perspective (Cambridge, 2008), $236-7$.

${ }^{12}$ B. McGowan, Economic life in the Ottoman Empire: taxation, trade and the struggle for land, 1600-1800 (Cambridge, 1981), ch. 1.

${ }^{13}$ Ariel Salzmann, Measures of empire: tax farmers and the Ottoman Ancien Régime, 1695-1807 (unpublished Ph.D. dissertation, Columbia University, 1995), 331; Ariel Salzmann, Tocqueville in the Ottoman Empire: rival paths to the modern state (Leiden and Boston, 2004), 60-71; R. Kasaba, The Ottoman Empire and the world economy: the nineteenth century (Albany, 1988), 14; Suraiya N. Faroqhi, 'Declines and revivals in textile production', in Suraiya N. Faroqhi ed., The Cambridge history of Turkey, vol. 3: The later Ottoman empire, 1603-1839 (Cambridge, 2006), 356-75, here 362; Mehmet Genç, 'Ottoman industry in the eighteenth century: general framework, characteristics, and main trends', in Donald Quataert ed., Manufacturing in the Ottoman Empire and Turkey, 1500-1950 (Albany, 1994), 69-70.

${ }^{14}$ Süleyman Özmucur and Şevket Pamuk, 'Real wages and the standards of living in the Ottoman Empire, 1469-1914', Journal of Economic History 62, 2 (2002), 293-321, here 301. Skilled wages remained flat. ${ }^{15}$ Canbakal, 'Reflections', 249. Canbakal does not adjust her observations for inflation. However, since prices declined during the two centuries, this does not change the inference of a declining trend in wealth levels. ${ }^{16}$ Mehmet Genç, 'A study of the feasibility of using eighteenth-century Ottoman financial records as an indicator of economic activity', in Huri İslamoğlu-İnan ed., The Ottoman Empire and the world economy (Cambridge, 1987), 345-73, here 358.

${ }^{17}$ Nikolai Todorov, The Balkan city, 1400-1900 (Seattle, 1983), 149-50.

${ }^{18}$ One exception is the finding by Canbakal that inequality increased in Ayntab between the seventeenth and eighteenth centuries; 'Reflections’, 287-8.

${ }^{19}$ Özkaya, Osmanlı Kurumları; McGowan, Economic life; M. Genç, 'Osmanlı Maliyesinde Malikane Sistemi’, in O. Okyar ed., Türkiye Ikktisat Tarihi Semineri (Ankara, 1973), 231-91; M. Çızakça, A comparative evolution of business partnerships: the Islamic world and Europe, with specific reference to Ottoman archives (Leiden, 1996), 159-69.

${ }^{20}$ See, now, Metin M. Coşgel and Boğaç A. Ergene, 'Inequality of wealth in the Ottoman Empire: war, weather, and long-term trends in eighteenth century Kastamonu’, Journal of Economic History 72, 2 (2012), 308-31. 
${ }^{21}$ Parts of the discussion on historical background and dataset are adapted from Coşgel and Ergene, 'Inequality of wealth'.

${ }^{22}$ B. A. Ergene, Local court, provincial society and justice in the Ottoman Empire: legal practice and dispute resolution in Çankırı and Kastamonu, 1652-1744 (Leiden, 2003), ch. 2.

${ }^{23}$ Cited in C. Behar ed., Osmanlı Imparatorluğu'nun ve Türkiye 'nin Nüfusu, 1500-1927 (Ankara, 1996$), 7$.

${ }^{24}$ J. M. Kinneir, Journey through Asia Minor, Armenia and Koordistan in the years 1813 and 1814: with remarks on the marches of Alexander and retreat of the ten thousand (London, 1818), 282. Kemal Eyüpgiller, who studied the urban history of the town, does not regard the period as one of major construction or urban expansion. He also claims that the boundaries of the town by the end of the nineteenth century were not much different from those in the sixteenth century. Kemal Kutgün Eyüpgiller, Bir Kent Tarihi: Kastamonu (Istanbul, 1999), 383-4. Charles Issawi gives the population of the town as 12,000 in the 1830s, 16,000 in 1890, and 20,000 in 1912. Cited in Behar, Osmanlı Imparatorluğu, 33.

${ }^{25}$ Ergene, Local court, ch. 2.

26 'Kastamonu’, Meydan Larousse, vol. 7 (Istanbul, 1969), 60.

27 Ibid.

${ }^{28}$ Suraiya Faroqhi, Towns and townsmen of Ottoman Anatolia: trade, crafts and food production in an urban setting, 1520-1650 (Cambridge, 1984), 131-5. Eyüpgiller, Bir Kent, 44-6.

${ }^{29}$ Ergene, Local court, ch. 2; Eyüpgiller, Bir Kent, 44-5; T. M. Yaman, 'Küre Bakır Madenine Dair Vesikalar', Tarih Vesikaları 1 (1941), 266-82; Faroqhi, Towns, 175.

${ }^{30}$ Faroqhi, Towns, 225-7; M. Karagöz, 'XVII. ve XVIII. Asırlarda (1650-1750) Kayseri', Fırat University Journal of Social Science 19 (2009), 266.

${ }^{31}$ Ergene, Local court, ch. 2.

${ }^{32}$ Boğaç A. Ergene and Ali Berker, 'Wealth and inequality in 18th-century Kastamonu: estimations for the Muslim majority’, International Journal of Middle East Studies 40, 1 (2008), 23-40.

${ }^{33}$ For detailed discussions of the contents of these documents and the ways in which they can be used to understand the material culture of a particular locale, see C. Establet and J.-P. Pascual, Familles et fortunes à Damas: 450 foyers damascains en 1700 (Damascus, 1994); and C. Establet and J.-P. Pascual, La gent d'état dans la société ottomane damascène: les 'askar à la fin du XVIIe siècle (Paris: Institut français du ProcheOrient, 2011).

${ }^{34}$ R. Gradeva, ‘Towards a portrait of “the rich” in Ottoman provincial society: Sofia in the 1670s', in A. Anastasopoulos ed., Provincial elite in the Ottoman Empire (Rethymno, Crete, 2005), 152-63; Colette Establet, Jean-Paul Pascual and André Raymond, 'La mesure de l’inégalité dans la société ottomane: utilisation de 
l'indice de Gini pour Le Caire et Damas vers 1700', Journal of the Economic and Social History of the Orient 37, 2 (1994), 171-82; Ergene and Berker, 'Wealth and inequality', 26.

35 The court of Kastamonu charged about 3.4 per cent of the gross values of estates for assessing their values and dividing them among heirs. See Bogaç A. Ergene, 'Costs of court usage in seventeenth- and eighteenthcentury Ottoman Anatolia: court fees as recorded in estate inventories', Journal of the Economic and Social History of the Orient 45, 1 (2002), 20-39, here 29.

${ }^{36}$ See Annalies Moors, Women, property and Islam. Palestinian experiences, 1920-1990 (Cambridge, 1995), ch. 3 for the prevalence of this practice in modern Palestine.

${ }^{37}$ Wrigley and Schofield give the crude death rate as 0.035 for preindustrial Italy and France and as 0.025 to 0.03 for preindustrial England and Wales. See E. A. Wrigley and R. S. Schofield, The population history of England, 1541-1871: a reconstruction (Cambridge, 2002), 181-2.

${ }^{38}$ C. Heywood, 'Kastamonu', in Encyclopedia of Islam, 2nd edn, vol. 4. (Leiden, 1978), 738.

39 Özmucur and Pamuk, 'Real wages'. We compared the consumer price index of Özmucur and Pamuk with the prices of select food and consumer products from the lists of official prices (narh) in Kastamonu court registers, which are consistent.

${ }^{40}$ Ergene and Berker, 'Wealth and inequality'.

${ }^{41}$ Our ability to think about wealth and inequality in different ways is restricted due to the limited nature of historical sources. For example, it is impossible to determine if the control of land, through tax farming or other means, became concentrated in fewer hands in eighteenth-century Kastamonu, since terekes do not provide information about land, which was technically owned by the state. On the other hand, a few historians have suggested, based on the experiences of a few prominent provincial families, that land control was becoming concentrated during our period in other locations in Anatolia and the Balkans; see, for examples, Barkey, Empire of difference, ch. 7; and Çağlar Keyder and Faruk Tabak eds., Landholding and commercial agriculture in the Middle East (Binghampton, 1991).

${ }^{42}$ For women, the slopes calculated for the Gini coefficient and wealth shares appear to be influenced by the aberrant values found for the sub-period of 1723 to 1732, which is why we offer in Table 2 a second set of slope calculations that exclude this decade.

${ }^{43}$ Genç, 'Malikane Sistemi’, 252.

${ }^{44}$ Svetla Ianeva, 'Financing the state? Tax-farming as a source of individual wealth in the nineteenth century', Oriens 37 (2009), 209-24. For a similar observation in the context of seventeenth-century Greece, see P. Fodor, 'Fur of lynx and arable land: the wealth of an Ottoman tax farmer in early seventeenth century', Oriens 27 (2009), 191-208. 
${ }^{45}$ Initially, Istanbul-based elites dominated public auctions in which tax farms were sold to the highest bidders. From the very start, however, these groups managed their investments indirectly, through local agents or subfarmers, many of whom were among the provincial elite. Later, the roles of the provincial elite expanded substantially. 'Over the course of eighteenth century', Pamuk notes, 'some 1,000 to 2,000 Istanbul based individuals, together with some 5,000 to 10,000 individuals based in the provinces, as well as innumerable contractors, agents, financiers, accountants and managers controlled an important share of the state's revenues'; Şevket Pamuk, 'The evolution of financial institutions in the Ottoman Empire, 1600-1914', Financial History Review 11, 1 (2004), 7-32, here 17.

${ }^{46}$ According to Pamuk, 'the greatest fortunes in the larger cities of Bursa and Edirne during the seventeenth century belonged to people who lent a large part of their assets'. Ş. Pamuk, A monetary history of the Ottoman empire (Cambridge, 2000), 80. Estate inventories provide information about the outstanding debts and credits of the deceased. However, the important question of how credit relations might have changed in Kastamonu during our period cannot be addressed here due to the scope of the article and space considerations.

${ }^{47}$ H. İnalc1k, 'Centralization and decentralization in Ottoman administration', in T. Naff and R. Owen eds., Studies in eighteenth century Islamic history (Carbondale, 1977), 27-52.

${ }^{48}$ Ryckbosch, 'Scarcity and prosperity’; Alfani, ‘Wealth inequalities’; van Zanden, 'Kuznets curve'; Soltow and van Zanden, Income and wealth.

${ }^{49}$ In Flanders, the increasing reliance of the economy on income from previously accumulated capital, such as financial assets and land holdings, in a period of economic stagnation, was the primary cause of worsening inequality; Ryckbosch, 'Scarcity and prosperity’, 21. In northern Italy, demographic fluctuations were the responsible factors; Alfani, 'Wealth inequalities'.

${ }^{50}$ Establet, Pascual and Raymond, 'La mesure de l’inégalité dans la société ottomane’, 171-82, here 177-80. ${ }^{51}$ Canbakal, 'Reflections', 248.

${ }^{52}$ For more on the historical meanings of these titles and others, see Ergene and Berker, 'Wealth and inequality'.

${ }^{53}$ Elite title-holders, in addition to being wealthy, were also more urban, legally literate, and less hesitant to use court services than the rest of the society. Since the relationship between non-elite titles, such as Beşe, Halife or Çelebi, and sources of human capital formation is less clear, we chose to include them in the omitted category along with individuals with no titles.

${ }^{54}$ Y. Cezar, Osmanlı Maliyesinde Bunalım ve Değişim Dönemi (XVIII. yy. dan Tanzimat'a Mali Tarih) (Istanbul, 1986), 68-74; Tabakoğlu, Gerileme Dönemi, 295-300.

55 Tabakoğlu Gerileme Dönemi; Özkaya, Osmanlı Kurumları. 
${ }^{56}$ M. Genç, '18. Yüzy1lda Osmanlı Ekonomisi ve Savaş', in M. Genç, ed. Osmanlı İmparator luğunda Devlet ve Ekonomi (İstanbul, 2000), 215-25.

${ }^{57}$ R. Murphey, Ottoman warfare, 1500-1700 (New Brunswick, 1998), 85-6, 181.

${ }^{58}$ Halil İnalc1k and Donald Quataert eds., An economic and social history of the Ottoman Empire, 1300-1914 (Cambridge, 1994); Virginia H. Aksan, Ottoman wars, 1700-1800: an empire besieged (Harlow, 2007).

${ }^{59}$ Ünal Akkemik, Nesibe Dağdeviren and Aliye Aras, 'A preliminary reconstruction (A.D. 1635-2000) of spring precipitation using oak tree rings in the western Black Sea region of Turkey’, International Journal of

Biometeorology 49, 5 (2005), 297-302. This study reconstructs a record of yearly precipitation from the rings of living and dead oak-trees in the P1narbaş1 region, located about 80 kilometres northwest of the modern city of Kastamonu.

${ }^{60}$ D. J. Stephens and T. J. Lyons, 'Rainfall-yield relationships across the Australian wheatbelt', Australian Journal of Agricultural Research 49, 2 (1998), 211-23; B. Özkan and H. Akçaöz, 'Impacts of climate factors on yields for selected crops in southern Turkey', Mitigation and Adaptation Strategies for Global Change 7 (2002), 367-80.

${ }^{61}$ In comparison, when we regressed the annual wealth averages (in natural logarithmic scale) on Time and elite titles only, we found the coefficient for Time as -0.007 , which was significant at 1 per cent. This value represents percentage annual change in wealth averages if we do not hold constant the wealth effects of war incidents, weather patterns and the post-1767 crisis.

62 The partial $F$ test, which determines if a group of variables collectively has any effect on a dependent variable $\left(\mathrm{H}_{0}: \beta_{\mathrm{j}}=\beta_{\mathrm{k}}=\beta_{\mathrm{l}}=\ldots=0\right)$, indicated that the joint wealth impact of the coefficients calculated for post-1767 economic crisis, wars and elevated precipitation levels was also statistically insignificant at 5 per cent.

${ }^{63}$ Because the number of years with 8 or more female terekes (31) is very small, a similar type of analysis for women generates unreliable results.

${ }^{64}$ Cezar, Osmanlı Maliyesi, 74, 135; Tabakoğlu, Gerileme Dönemi, 295-300.

${ }^{65}$ Cezar, Osmanlı Maliyesi, 110

${ }^{66}$ Genc, 'Malikane Sistemi', 252.

${ }^{67}$ The partial $F$ test indicated that the joint impact of the war variables is also statistically insignificant at 5 per cent in the regressions for the second quartile.

${ }^{68}$ Ianeva, 'Financing the state', 211-12.

${ }^{69}$ The $F$ tests indicate that for the second, third and fourth quartiles the joint effects of the wet variables are insignificant at 5 per cent. 
${ }^{70}$ According to the $F$ test, the joint effect of the dry variables is insignificant at 5 per cent in the regression for the second quartile.

${ }^{71}$ When we regressed the yearly wealth averages (in natural logarithmic scale) on Time and elite titles only, we found the coefficients for Time as $-0.003,-0.005,-0.009,-012$ and -0.013 , respectively, for the top 10 per cent, first quartile, second quartile, third quartile and fourth quartile. The coefficients estimated for the top 10 per cent and first quartile were statistically insignificant; the coefficients for the second, third and fourth quartiles were significant at 1 per cent.

${ }^{72}$ See Coşgel and Ergene, 'Inequality of wealth', for a quantitative investigation of this issue. 